\title{
Normal mouse intestinal mucus release requires cystic fibrosis transmembrane regulator-dependent bicarbonate secretion
}

\author{
Mary Abigail S. Garcia, ${ }^{1}$ Ning Yang, ${ }^{2,3}$ and Paul M. Quinton ${ }^{3,4}$ \\ ${ }^{1}$ Division of Pediatric Gastroenterology, Hepatology, and Nutrition, Department of Pediatrics, University of California School of Medicine, San Diego, California, USA. \\ 2Department of Physiology, Capital Medical University, Beijing, China. ${ }^{3}$ Division of Pediatric Pulmonology, Department of Pediatrics, \\ University of California School of Medicine, San Diego, California, USA. ${ }^{4}$ Division of Biomedical Sciences, \\ University of California, Riverside, California, USA.
}

\begin{abstract}
The mechanisms underlying mucus-associated pathologies in cystic fibrosis (CF) remain obscure. However, recent studies indicate that $\mathrm{CF}$ transmembrane conductance regulator (CFTR) is required for bicarbonate $\left(\mathrm{HCO}_{3}^{-}\right)$transport and that $\mathrm{HCO}_{3}{ }^{-}$is critical for normal mucus formation. We therefore investigated the role of $\mathrm{HCO}_{3}{ }^{-}$in mucus secretion using mouse small intestine segments ex vivo. Basal rates of mucus release in the presence or absence of $\mathrm{HCO}_{3}{ }^{-}$were similar. However, in the absence of $\mathrm{HCO}_{3}{ }^{-}$, mucus release stimulated by either $\mathrm{PGE}_{2}$ or 5-hydroxytryptamine (5-HT) was approximately half that stimulated by these molecules in the presence of $\mathrm{HCO}_{3}{ }^{-}$. Inhibition of $\mathrm{HCO}_{3}{ }^{-}$and fluid transport markedly reduced stimulated mucus release. However, neither absence of $\mathrm{HCO}_{3}{ }^{-}$nor inhibition of $\mathrm{HCO}_{3}{ }^{-}$transport affected fluid secretion rates, indicating that the effect of $\mathrm{HCO}_{3}{ }^{-}$removal on mucus release was not due to decreased fluid secretion. In a mouse model of CF (mice homozygous for the most common human CFTR mutation), intestinal mucus release was minimal when stimulated with either $\mathrm{PGE}_{2}$ or 5-HT in the presence or absence of $\mathrm{HCO}_{3}{ }^{-}$. These data suggest that normal mucus release requires concurrent $\mathrm{HCO}_{3}{ }^{-}$secretion and that the characteristically aggregated mucus observed in mucin-secreting organs in individuals with CF may be a consequence of defective $\mathrm{HCO}_{3}{ }^{-}$transport.
\end{abstract}

\section{Introduction}

After more than 50 years, there is still little consensus for a common cause of mucus accumulation in the lung, intestine, and various other organs affected in cystic fibrosis (CF). No characteristic changes in mucin composition have been found in $\mathrm{CF}$ that uniformly explain the basis of the aggregated luminal mucus in CF intestines, airways, exocrine glands, and reproductive organs. Certain changes in the carbohydrate side chains have been reported, such as alterations in fucosylation (1), sulfation $(2,3)$, and sialylation (3), but these findings also occur in other chronic inflammatory states $(3,4)$. Disulphide bonds, which are critical to the macromolecular structure of mucins, were not found to be significantly changed in CF mucus (5), nor is there evidence of increased synthesis of the major intestinal mucins Muc2 and Muc3 in CF mice compared with WT (6). Counterintuitively, perhaps, the main mucins, Muc5AC and Muc5B, have been reported as decreased in CF airways (7). It seems unlikely that there is either an inherent qualitative or quantitative abnormality unrelated to CF mucin composition since we now know that different organs express different types of mucins (8), and yet all exhibit a similar pathology. Whether in CF lungs, pancreas, hepatobiliary tract, reproductive tract, exocrine glands, or intestine, mucus appears to be abnormally thick and viscid. Principal findings in these organs are aggregated mucus adherent to the mucosal surfaces as well as plugging of lumens and crypts with mucoid secretions (9). These observations suggest that changes in the density, transportability, and viscoelastic properties of CF mucus arise during the postexocytotic secretory process.

Conflict of interest: The authors have declared that no conflict of interest exists. Citation for this article: J. Clin. Invest. 119:2613-2622 (2009). doi:10.1172/JCI38662.
For example, sodium (fluid) hyperabsorption via hyperactive epithelial $\mathrm{Na}^{+}$channels (ENaC) in CF airways is widely thought to result in decreased epithelial surface fluid and therefore, thicker, "dehydrated" mucus (10); however, this rationale is hard to apply to the ducts of the pancreas, biliary tree, or small bowel where there are no known ENaC-dependent sodium absorptive mechanisms. In addition, if large increases in mucin concentration in vitro are required to significantly alter its viscoelasticity (5), it is not clear how mucus could become significantly desiccated in the aqueous environments of secretory lumens, especially since secretory epithelia are thought to be characteristically leaky and highly permeable to water (11).

If dehydration cannot completely unify the mucus abnormality, what does? Mucus swelling and hydration during the process of exocytosis is governed by Donnan effects rather than by simple osmosis (12). This means that the driving force for swelling is not merely due to water availability, but also and mainly due to the polyanionic charges fixed to mucins that are strongly influenced by the $\mathrm{pH}$ and ionic strength of the aqueous medium (13), that is, by the composition of the luminal electrolyte and fluid environment, which depends crucially upon epithelial ion transport.

The most evident cellular defect in CF is the loss of $\mathrm{Cl}^{-}$transport caused by mutations in the gene for CF transmembrane conductance regulator (CFTR), which is essential in several systems of fluid and electrolyte transport. However, it is now recognized that the CFTR channel is also required for bicarbonate $\left(\mathrm{HCO}_{3}{ }^{-}\right)$ transport (14-16). Strikingly, the phenotype of the pancreas, perhaps the most acknowledged organ of $\mathrm{HCO}_{3}{ }^{-}$transport, segregates well with genotypes that severely disrupt CFTR-dependent $\mathrm{HCO}_{3}{ }^{-}$ transport in this organ and in the sweat duct $(15,17)$. Likewise, $\mathrm{HCO}_{3}{ }^{-}$secretion is reduced in the CF intestine $(16,18,19)$. More- 

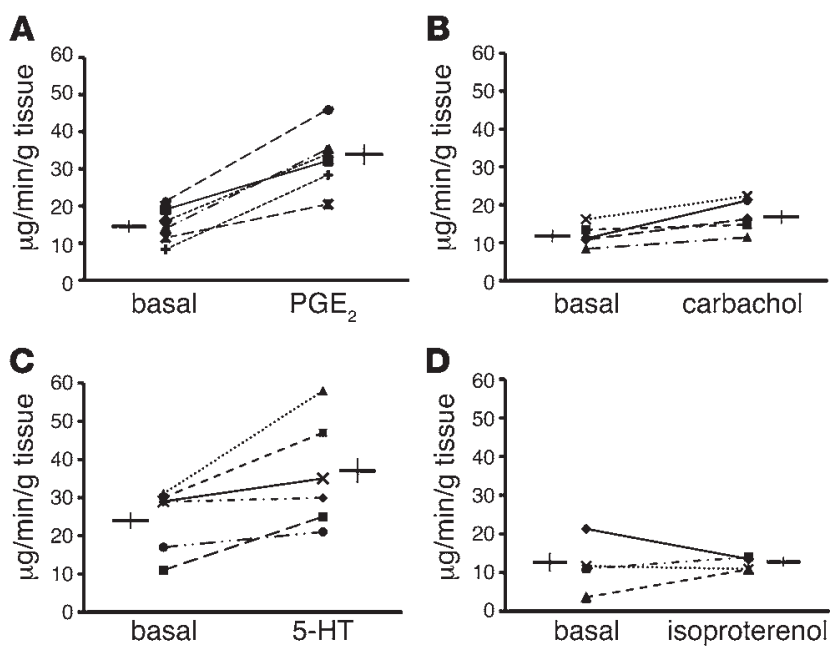

\section{Figure 1}

Effect of secretagogues on mucus release. Differences between amounts of mucus released in luminal perfusates are shown before (basal) and after stimulation with $\mathrm{PGE}_{2} 10^{-6} \mathrm{M}(n=6, P<0.001)(\mathbf{A})$, carbachol $10^{-4} \mathrm{M}(n=5, P=0.024)(\mathrm{B})$, and $5-\mathrm{HT} 10^{-5} \mathrm{M}(n=6$, $P=0.03)(C)$. These agonists significantly increased mucus release. On the other hand, isoproterenol $10^{-5} \mathrm{M}$ did not stimulate mucus release $(n=4, P=0.9)$ (D). Data shown are mean \pm SEM.

over, experimentally altering $\mathrm{HCO}_{3}{ }^{-}$secretion appeared to change mucus consistency in submucosal gland secretion in sheep, pigs, and human trachea (20). Notably, ductal $\mathrm{HCO}_{3}{ }^{-}$was also critical for dispersing aggregated enzymes released into the acinar lumen of the pancreas (21).

These observations indicate that the failure to secrete $\mathrm{HCO}_{3}$ may be a common pathogenic effect in abnormal mucus release in $\mathrm{CF}$. We therefore evaluated the role of $\mathrm{HCO}_{3}{ }^{-}$transport in mouse distal small intestine, the most common location of intestinal obstruction in mouse models and in CF patients, by monitoring the amount of mucus acutely released into the lumen while altering conditions known to affect $\mathrm{HCO}_{3}{ }^{-}$secretion. Herein, we use the term "release" to encompass what we believe are postexocytotic extracellular events apart from those that occur intracellularly in the overall process of mucus secretion. We found that deficient $\mathrm{HCO}_{3}{ }^{-}$secretion significantly decreased mucus released from this tissue. We interpret these results as consistent with a role for $\mathrm{HCO}_{3}{ }^{-}$in expanding and possibly solubilizing mucins postexocytotically by sequestering cations that keep stored mucins highly condensed in intracellular granules (22). If our interpretation is correct, poor $\mathrm{HCO}_{3}{ }^{-}$secretion in $\mathrm{CF}$ contributes to the unique "mucoviscidosis" used years ago to describe this disease (23).

\section{Results}

Since this preparation presents an original approach to monitoring mucus release from native tissue ex vivo, we first addressed several difficulties that were initially encountered in implementing this system.

Peristalsis interferes. We found that the continual looping, bending, and stretching of the isolated intestine due to spontaneous peristalsis continued constitutively for more than an hour after excision. These activities caused sporadic release of mucus during sequential collections that complicated interpretation of stimulusinduced mucus release. In attempts to reduce peristalsis, we tested the effects of tetrodotoxin (TTX) $10^{-5} \mathrm{M}$ (voltage-gated neuronal $\mathrm{Na}^{+}$channel blocker), clonidine $10^{-4} \mathrm{M}$ ( $\alpha$-2 adrenergic agonist), atropine $10^{-6} \mathrm{M}$ (acetylcholine antagonist), indomethacin $10^{-6} \mathrm{M}$ (cyclooxygenase inhibitor), and hexamethonium $10^{-6} \mathrm{M}$ (nicotinic receptor blocker), but none of these agents completely blocked peristalsis within 1 hour. $\mathrm{K}^{+}$-free Ringer solution inhibited peristalsis within about 40 minutes, but nifedipine $10^{-6} \mathrm{M}$, an L-type calcium channel blocker (24), inhibited peristalsis within 1 minute after adding the drug. Nifedipine did not appear to block fluid secretion in isolated intestinal segments (see below) and did not affect $\mathrm{Ca}^{2+}$-dependent secretion from isolated human sweat glands (A.K. Shamsuddin, unpublished observations).

$P G E_{2}$ and 5-hydroxytryptamine stimulate mucus release. While several agonists have been reported to induce mucus secretion under various conditions, our purpose here required agonists that acutely induce mucus secretion ex vivo. We added several putative secretagogues in $\mathrm{HCO}_{3}{ }^{-}$-free serosal PBS Ringer solutions in the presence
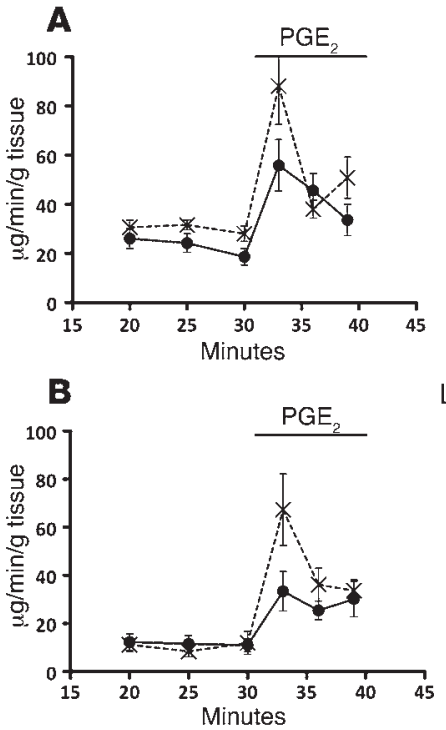

PAS

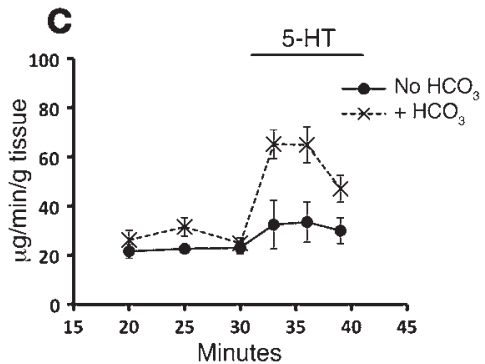

Lectin

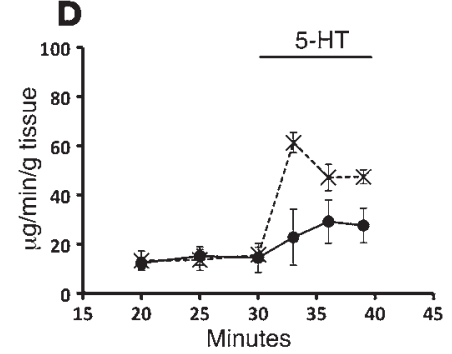

Figure 2

Effect of $\mathrm{HCO}_{3}{ }^{-}$on $\mathrm{PGE}_{2-}$ and 5-HT-induced mucus release. At 20 minutes, the bathing solution on one segment of intestine was changed to $\mathrm{HCO}_{3}{ }^{-}$Ringer (x's), while the other segment remained in $\mathrm{HCO}_{3}{ }^{-}$-free Ringer (circles). Application of $\mathrm{PGE}_{2}$ or $5-\mathrm{HT}$ at 30 minutes caused a marked increase in mucus secretion in both groups, but the amount of mucus released was significantly reduced in the absence of $\mathrm{HCO}_{3}{ }^{-}$with either $\mathrm{PGE}_{2}(\mathbf{A}$ and $\mathbf{B}$ ) or 5-HT (C and D). (A) $n=5, P<0.002$. (B) $n=8, P=0.026$. (C) $n=5, P<0.001$. (D) $n=8$, $P=0.001$. Samples from protocols represented in panels $\mathbf{A}$ and $\mathbf{C}$ were assayed with PAS; results of lectin binding assays of the same samples are shown in panels $\mathbf{B}$ and $\mathbf{D}$. Data shown are mean \pm SEM. 

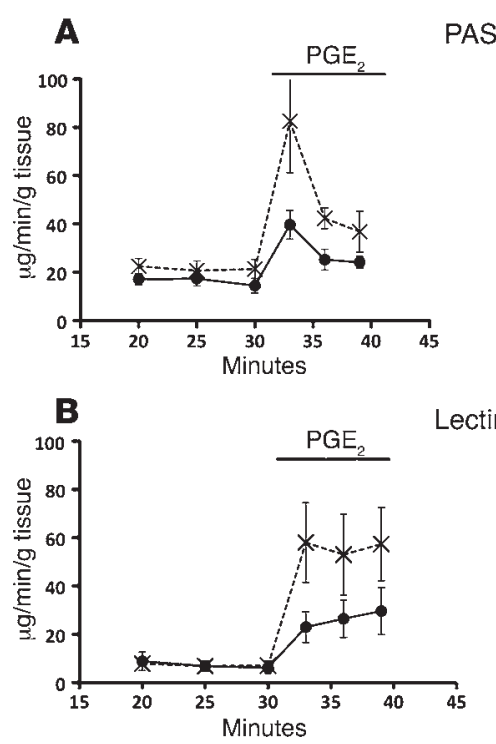
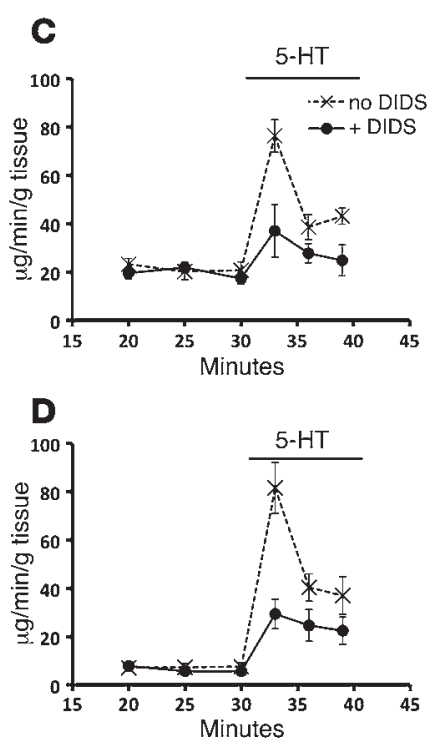

\section{Figure 3}

Effect of DIDS on mucus release. Compared with control (x's), DIDS (circles) applied to the serosal solutions to inhibit $\mathrm{HCO}_{3}{ }^{-}$ secretion consistently depressed mucus release stimulated by $\mathrm{PGE}_{2}(\mathbf{A}$ and $\mathbf{B})$ and by 5-HT (C and $\left.\mathbf{D}\right)$ compared with controls without DIDS. (A) $n=9, P=0.001$. (B) $n=6, P=0.002$. (C) $n=10$, $P=0.002$. (D) $n=8, P=0.002$. DIDS application reduced mucus release by $50 \%-70 \%$. All segments were bathed continuously in $\mathrm{HCO}_{3}{ }^{-}$Ringer solution. Samples were assayed by PAS and lectin binding as noted in Figure 2. Data shown are mean \pm SEM. of nifedipine and assayed the perfusate for increases in mucus content. Consistent with previous studies, cAMP-mediated agonists, such as $\mathrm{PGE}_{2}$, as well as $\mathrm{Ca}^{2+}$-mediated agonists, such as carbachol, stimulated significant mucus release. $\mathrm{PGE}_{2}$, however, proved to have a larger effect on the rate of mucus release (Figure $1 \mathrm{~A}$ ) at a lower concentration $\left(10^{-6} \mathrm{M}\right)$ compared with carbachol $\left(10^{-4} \mathrm{M}\right)$, which appears to be a relatively weak agonist (Figure 1B). Preliminary dose-response assays with $\mathrm{PGE}_{2}$ showed that mucus secretion peaked between $10^{-7}$ and $10^{-6} \mathrm{M}$ and did not increase with higher doses (>10-6 M). Serotonin (5-hydroxytryptamine [5-HT]), a neuroendocrine substance found abundantly in the intestinal tract, also increased mucus release significantly when applied $\left(10^{-5} \mathrm{M}\right)$ serosally (Figure $1 \mathrm{C})$, but isoproterenol $\left(10^{-5} \mathrm{M}\right)$, a cAMP-dependent $\beta$-adrenergic agonist, did not significantly increase mucus secretion (Figure 1D). These results confirmed that the intestine could be stimulated to mount a robust mucus secretion ex vivo in response to specific agonists up to an hour after resection. Based on these findings, we applied $\mathrm{PGE}_{2}$ as an agonist of choice for acute stimulation in the subsequent experiments and used 5-HT as a supplementary secretagogue to corroborate findings with $\mathrm{PGE}_{2}$-stimulated mucus secretion.

Removing $\mathrm{HCO}_{3}{ }^{-}$depresses stimulated mucus release. To determine whether mucus release requires $\mathrm{HCO}_{3}{ }^{-}$, we replaced it with $\mathrm{Cl}^{-}$ under constitutive (basal) and stimulated conditions. The basal release of mucus was similar in the presence and absence of serosal $\mathrm{HCO}_{3}{ }^{-}$. However, when the intestine was stimulated with $\mathrm{PGE}_{2}$ in $\mathrm{HCO}_{3}{ }^{-}$-free media, mucus release was consistently and significantly reduced compared with $\mathrm{HCO}_{3}{ }^{-}$-containing media as reflected by both PAS and lectin assays (Figure 2, A and B). To ensure that the results were not unique to $\mathrm{PGE}_{2}$ stimulation, we also stimulated mucus release with 5-HT, which was also markedly decreased by about $50 \%$ in the absence of $\mathrm{HCO}_{3}{ }^{-}$(Figure 2, C and D). Carbachol-stimulated mucus release was also consistently less in the absence of $\mathrm{HCO}_{3}^{-}$, but the difference did not reach statistical significance, possibly due to the weaker stimulatory effects of carbachol and the smaller number of experiments performed ( $n=4, P=0.2$; data not shown).

Inbibiting NBC depresses mucus release. To further ensure that the inhibitory effect of $\mathrm{HCO}_{3}{ }^{-}$-free solutions was on $\mathrm{HCO}_{3}{ }^{-}$secretion, we added 4,4'-diisothiocyano-2,2'-stilbenedisulfonate (DIDS) $\left(2 \times 10^{-4} \mathrm{M}\right)$ to serosal medium containing $\mathrm{HCO}_{3}{ }^{-}$to inhibit the basolateral $\mathrm{Na}^{+} / \mathrm{HCO}_{3}{ }^{-}$cotransporter (NBC) and block $\mathrm{HCO}_{3}{ }^{-}$ secretion (25). The mucus released was reduced to about $50 \%$ of that of the paired control segment without inhibitor. Inhibition occurred with stimulation by either $\mathrm{PGE}_{2}$ or 5 -HT (Figure $3, \mathrm{~A}-\mathrm{D}$ ) and was similar to the effect of removing $\mathrm{HCO}_{3}{ }^{-}$as above. We also examined the effects of carbonic anhydrase inhibitor, acetazolamide $\left(10^{-5} \mathrm{M}\right)$, on inhibiting mucus release, but found no detectable effect. With $\mathrm{HCO}_{3}{ }^{-}$present in the serosal bath, stimulated

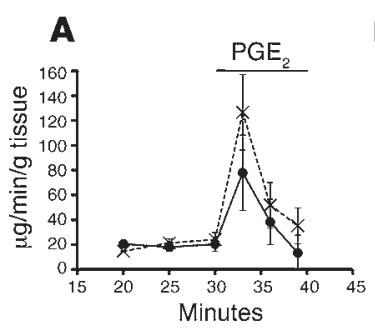

PAS
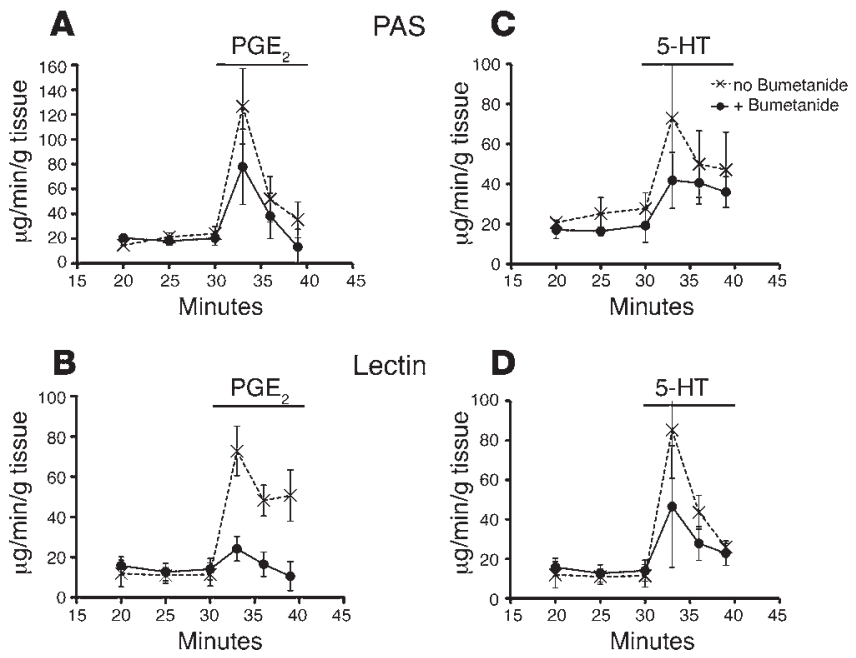

Lectin

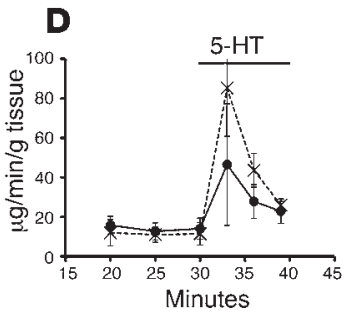

\section{Figure 4}

Effect of bumetanide on mucus release. Application of NKCC inhibitor bumetanide (circles) to the basolateral side to inhibit fluid secretion consistently decreased stimulated mucus release compared with control without inhibitor (x's). Mucus release was significantly lower with the inhibitor with each agonist as determined by each assay: $\mathrm{PGE}_{2}(\mathbf{A}$ and B) and 5-HT (C and D). (A) $n=3, P=0.041$. (B) $n=4, P=0.003$. (C) $n=3, P=0.039$. (D) $n=4, P=0.036$. All segments were bathed continuously in $\mathrm{HCO}_{3}{ }^{-}$Ringer solution. Samples were assayed by PAS and lectin binding as noted in Figure 2. Data shown are mean \pm SEM. 


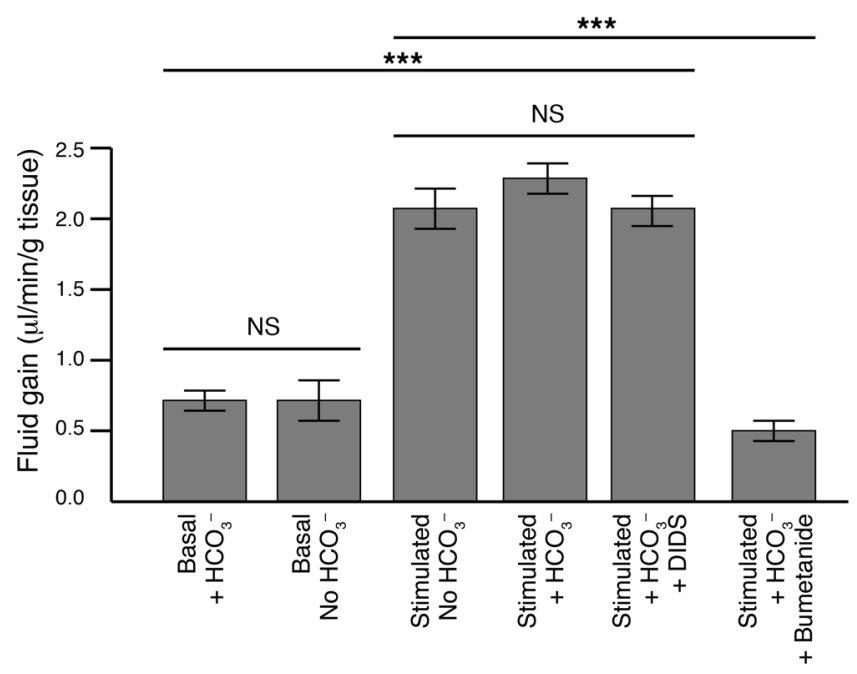

mucus release in the presence of acetazolamide was $33.3 \pm 7.8$ and in its absence $28.2 \pm 2.9 \mu \mathrm{g} / \mathrm{min} / \mathrm{g}$ tissue $(n=7 ; P=0.52)$.

Inbibiting NKCC depresses mucus release. To determine whether concurrent fluid secretion is necessary to transport mucus into the luminal perfusate $(26,27)$, we added bumetanide $\left(10^{-4} \mathrm{M}\right)$ to $\mathrm{HCO}_{3}{ }^{-}$-containing serosal solutions to selectively block the Na$\mathrm{K}-2 \mathrm{Cl}$ cotransporter (NKCC) and inhibit fluid secretion (28). We found that the amount of mucus released into the perfusate was significantly decreased in both $\mathrm{PGE}_{2}$ - and 5-HT-stimulated conditions (Figure 4, A-D). These results indicate that fluid secretion is also required for optimal release of mucus into luminal fluids, possibly serving to lavage secreted mucus from crypts and from between villi into the intestinal lumen.

Removing $\mathrm{HCO}_{3}{ }^{-}$does not affect fluid secretion. Since both removal of $\mathrm{HCO}_{3}{ }^{-}$and inhibition of fluid secretion decreased mucus release, we determined whether decreased mucus release in the absence of $\mathrm{HCO}_{3}{ }^{-}$might be due to decreased fluid secretion caused by removing $\mathrm{HCO}_{3}{ }^{-}$. We compared fluid secretion rates with and without $\mathrm{HCO}_{3}{ }^{-}$in closed intestinal sacs. Since the intestine both reabsorbs and secretes fluid concurrently, we removed the absorptive component by replacing luminal $\mathrm{NaCl}$ in the luminal Ringer solution with an impermeable salt, ( $N$-methyl-D-glucamine-gluconate) NMDG-gluconate. Fluid secretion rates were not significantly different when stimulated with either $\mathrm{PGE}_{2}$ or 5 -HT or both agonists combined, so for simplicity, both agonists were combined to stimulate mucus release. Upon stimulation, fluid secretion increased markedly, as evidenced by an increase in the weight of the closed sacs, which was completely blocked by bumetanide. Removing $\mathrm{HCO}_{3}{ }^{-}$from the bath had no detectable effect on basal or stimulated fluid secretion. Likewise, DIDS $\left(2 \times 10^{-4} \mathrm{M}\right)$ did not reduce fluid secretion (Figure 5).

\section{Figure 6}

Effect of CFTR inhibition on mucus release. Application of CFTR inhibitor GlyH-101 inhibited mucus release stimulated by either $\mathrm{PGE}_{2}(\mathbf{A}-\mathbf{B})$ or 5-HT (C-D) even in the presence of $\mathrm{HCO}_{3}{ }^{-}$(x's) compared with control segments without inhibitor (circles). (A) $n=5, P<0.001$. (B) $n=4$, $P=0.002$. (C) $n=4, P=0.036$. (D) $n=4, P=0.056$. All segments were bathed continuously in $\mathrm{HCO}_{3}{ }^{-}$solution. Samples were assayed by PAS and lectin binding as noted in Figure 2. Data shown are mean \pm SEM.

\section{Figure 5}

Effect of $\mathrm{PGE}_{2}$ and $5-\mathrm{HT} \pm \mathrm{HCO}_{3}{ }^{-}$on fluid movement in isolated intestinal loops. In the absence of luminal $\mathrm{Na}^{+}$and $\mathrm{Cl}^{-}$, the intestine demonstrated net secretion (fluid gain) during 30 minutes of incubation. When the intestinal sacs were exposed to $\mathrm{PGE}_{2}\left(10^{-6} \mathrm{M}\right)$ and $5-\mathrm{HT}\left(10^{-5} \mathrm{M}\right)$ simultaneously, fluid secretion increased dramatically ( $\left.n=4,{ }^{* * *} P=0.0001\right)$. Removal of $\mathrm{HCO}_{3}{ }^{-}$did not diminish basal ( $n=4, P=0.972)$ or stimulated fluid secretion $(n=4, P=0.942)$, nor did application of DIDS decrease fluid secretion $(n=4, P=0.922)$ when compared with stimulation in media with $\mathrm{HCO}_{3}{ }^{-}$. However, bumetanide notably inhibited stimulated fluid secretion $(n=4)$. Luminal $\mathrm{NaCl}$ was replaced by the impermeable salt NMDG-gluconate to prevent confounding effects from concurrent fluid absorption. Data shown are mean \pm SEM.

Mucus release requires CFTR. Defective mutant CFTR is associated with defective $\mathrm{HCO}_{3}{ }^{-}$secretion and the presence of thick, viscid mucus in CF-affected organs. To evaluate the possible role of CFTR in mucus release, we applied the CFTR selective inhibitor GlyH-101 (29) $\left(2 \times 10^{-5} \mathrm{M}\right)$ to luminal perfusate and bath solutions. GlyH-101 effectively blocked both $\mathrm{PGE}_{2}$ - and 5-HT-stimulated mucus release (Figure 6, A-D).

Moreover, intestinal segments from $\Delta$ F508 mice gave minimal responses to stimulation, and removing $\mathrm{HCO}_{3}{ }^{-}$did not significantly affect the amount of mucus released by stimulated mutant CFTR epithelia (Figure 7), suggesting that the defect in $\mathrm{HCO}_{3}{ }^{-}$ transport caused by $\Delta 508$ CFTR precludes the effects of removing $\mathrm{HCO}_{3}{ }^{-}$on mucus secretion in $\mathrm{CF}$.

Luminal $\mathrm{HCO}_{3}{ }^{-}$does not enhance mucus secretion. Since mucus release appeared to be dependent on secretion of serosal $\mathrm{HCO}_{3}{ }^{-}$ into the lumen, we determined whether perfusing the lumen with $\mathrm{HCO}_{3}{ }^{-}$in the absence of serosal $\mathrm{HCO}_{3}{ }^{-}$would similarly support increases in mucus release. We perfused intestinal segments of WT mice with $\mathrm{HCO}_{3}{ }^{-}$Ringer solution only in the lumen. In this case, however, mucus release was similar in both conditions (Figure 8). The lack of significant effects of luminal $\mathrm{HCO}_{3}{ }^{-}$suggests that $\mathrm{HCO}_{3}{ }^{-}$must be secreted concomitantly with mucus.
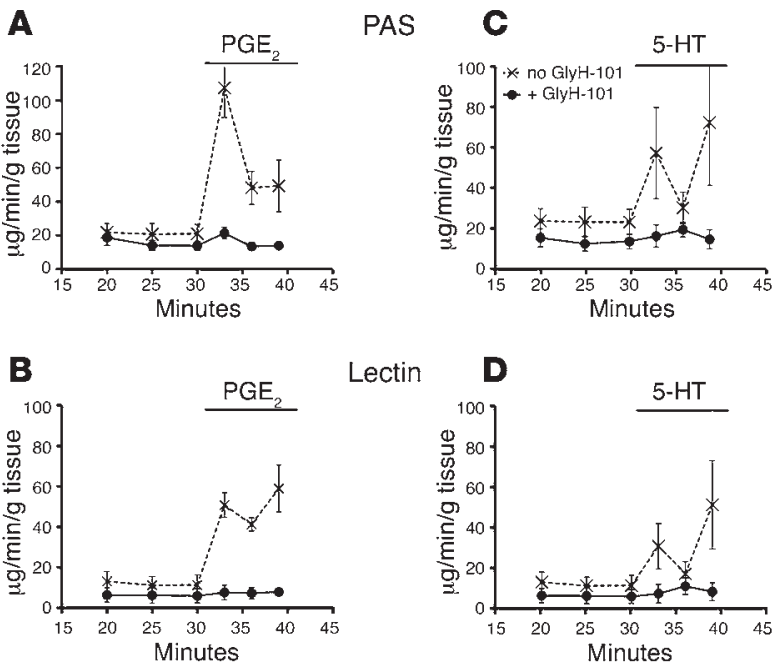

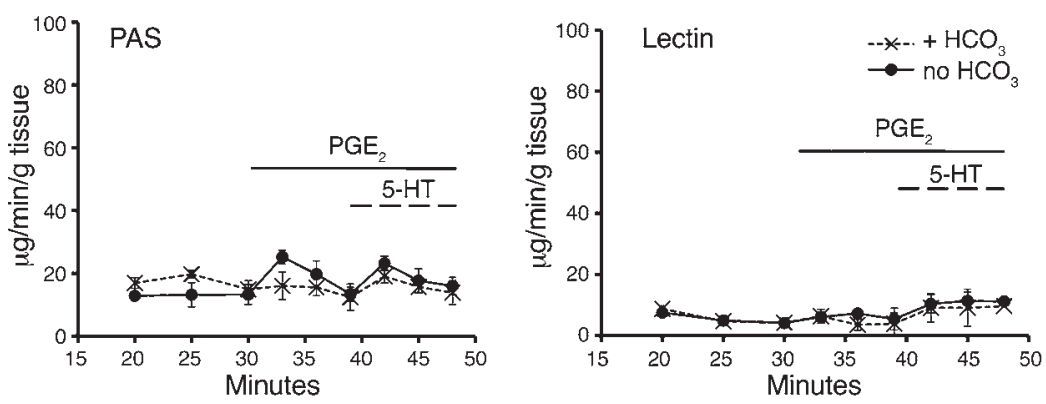

\section{Figure 7}

Response of mucus release in $\Delta \mathrm{F} 508$ mice. Mice homozygous for the $\Delta \mathrm{F} 508$ mutation showed blunted response to stimulation by $\mathrm{PGE}_{2}\left(10^{-6} \mathrm{M}\right)$ and $5-\mathrm{HT}$ $\left(10^{-5} \mathrm{M}\right)$. The amount of mucus release did not seem to differ between segments with $\mathrm{HCO}_{3}{ }^{-}$(x's) and those without $\mathrm{HCO}_{3}{ }^{-}$(circles) for stimulation with $\mathrm{PGE}_{2}$ (PAS, $n=5, P=0.210$; lectin, $n=5, P=0.185$ ) or with $5-\mathrm{HT}$ (PAS, $n=5, P=0.475$; lectin, $n=5, P=0.434$ ). Data shown are mean \pm SEM.

\section{Discussion}

The complexities of mucin molecules and the numerous events associated with the secretion of mucus present enormous challenges to defining and understanding the production of mucus to protect epithelial surfaces. The mechanisms of mucin unfolding and the immense expansion that occurs during and after exocytosis are particularly complex. While malfunctions of these mechanisms may underlie any number of epithelial pathologies ranging from asthma to gastrointestinal ulcers, we focused on CF because it is clearly a disease that involves a mucus abnormality that seems to arise postexocytotically in multiple exocrine organs. This fact alone suggests that certain conditions and events must be common to mucin secretion in general as well as to a common defect that gives rise to the characteristic, widespread mucus abnormality in CF, whose almost antiquated, but appropriate, synonym is "mucoviscidosis" (state of thick mucus) (23). Thus, this specific disease may be instructive in understanding events associated with mucus formation in general.

\section{Mucus stimulation}

Perfusion system. Although great advances have been made in recent years in identifying distinct mucin genes and types of mucins, most studies of mucus release have focused on histological changes associated with mucus-secreting cells and the thickness of the extrinsic mucus layers on epithelia (26, 30-32). To study properties of dynamic mucus secretion, we constructed a custom-designed ex vivo perfusion system (Figure 9) to follow the temporal release of mucins from the intestine. The preparation consisted of a vertical perfusing system whereby samples of luminal perfusates were collected sequentially and assayed for mucus content. The upward, vertical perfusion arrangement maintained a small, constant positive pressure in the lumen to maintain patency. However, constitutive peristaltic waves interfered with consistent measures of mucus release. We circumvented this problem with nifedipine, a smooth muscle L-type
$\mathrm{Ca}^{2+}$ channel blocker that completely blocked peristalsis almost immediately upon application (24). Nifedipine is reported to inhibit fluid secretion in the gut, but its action seems to be indirect via inhibition of the neuronal release of 5-HT (33). In the present studies, 5-HT was added exogenously to all preparations so that it seems unlikely that nifedipine would have interfered with secretory functions investigated here.

Mucus secretagogues. Both $\mathrm{PGE}_{2}$ and 5- $\mathrm{HT}$ are reported to stimulate $\mathrm{Cl}^{-}, \mathrm{HCO}_{3}^{-}$, and mucus secretion (34-37). Both agonists are endogenous to the intestine and known to be involved in both physiological functions and pathological conditions in the gut. $\mathrm{PGE}_{2}$ may act more potently among the secretagogues we tested because it may stimulate both cAMP-mediated (EP4 receptor) and $\mathrm{Ca}^{2+}$-mediated (EP3 receptor) pathways as reported for duodenal secretion (38), as well as effectively stimulating intestinal $\mathrm{HCO}_{3}{ }^{-}$ secretion (36). Moreover, since mucus in the small intestine derives from different cells (crypts and villi), $\mathrm{PGE}_{2}$ may activate multiple cell types and/or multiple pathways in the same cell.

5 -HT is ubiquitously present in the gastrointestinal tract and acts in intestinal fluid secretion and in sensory signaling for mucosal protection via receptors that are activated from the basolateral surface (37). It seems likely that the potent effects of 5-HT may also be due to activation of multiple pathways and different cell types, especially since its release is mediated normally by neuronal activity. If these agonists stimulate different cells or different pathways, the fact that both $\mathrm{PGE}_{2}$ and 5-HT produced almost identical results on mucus release could argue that the effects of $\mathrm{HCO}_{3}{ }^{-}$are general and not limited to a specific cell type or pathway.

The weaker effects of carbachol and the lack of effect of isoproterenol may be due to the possibility that they activate fewer (only 1 ) components of a stimulus response.

\section{Intestinal mucus release}

Mucin glycoproteins in the small intestine originate from distinct sources: goblet cells in the crypts of Lieberkuhn, goblet cells in

\section{Figure 8}

Effect of luminal $\mathrm{HCO}_{3}{ }^{-}$on mucus release. In contrast with serosal $\mathrm{HCO}_{3}{ }^{-}$, no significant difference in the amount of mucus release was noted when $\mathrm{HCO}_{3}{ }^{-}$was applied to the luminal side (x's) compared with segments $(n=8)$ perfused without luminal $\mathrm{HCO}_{3}{ }^{-}$(circles). $\mathrm{PGE}_{2}$ (PAS, $n=8, P=0.634$; lectin, $n=7$, $P=0.576$ ) and 5-HT (PAS, $n=8, P=0.743$; lectin, $n=7, P=0.762$ ) were added sequentially at 30 minutes and at 39 minutes, respectively. Data shown are mean \pm SEM.
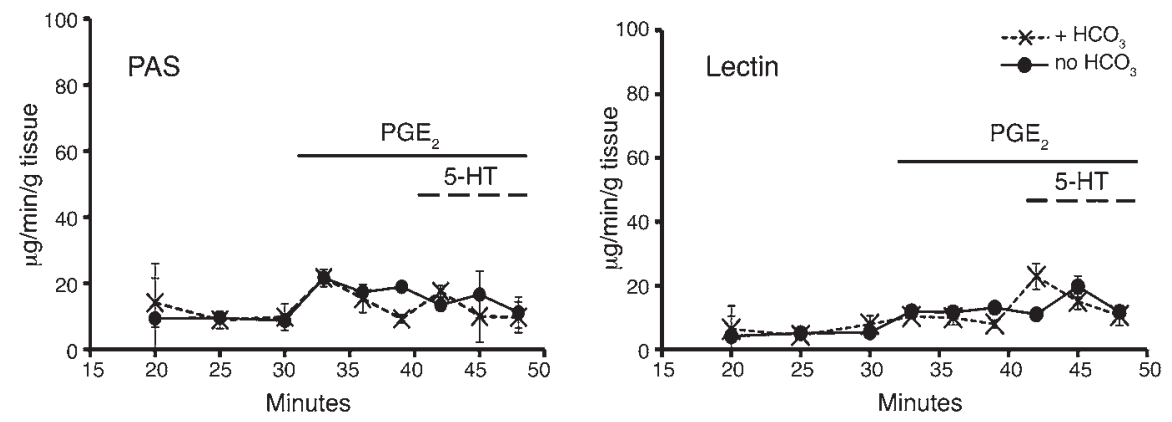


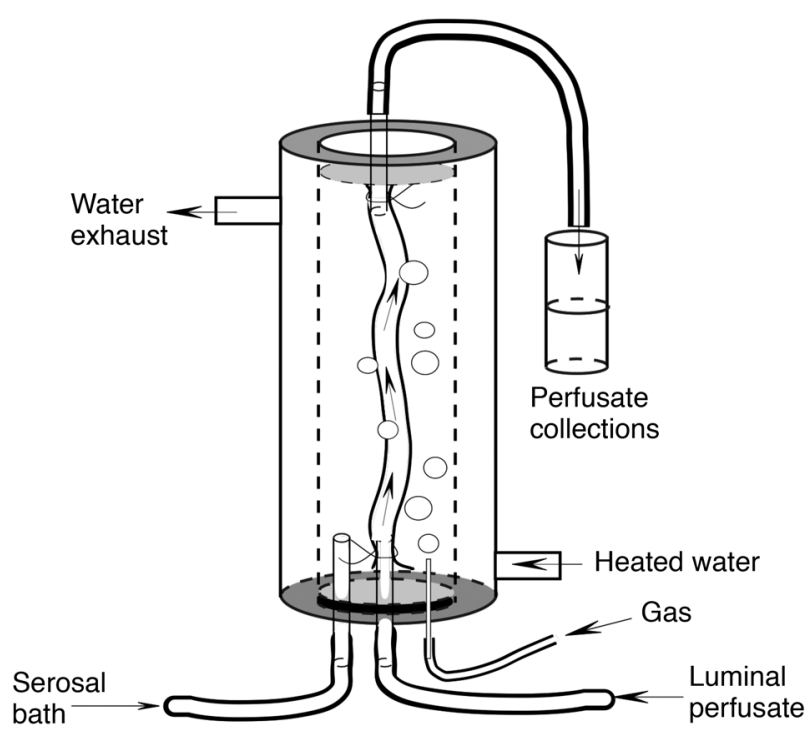

the villar surfaces, and villar epithelial cells per se may add significantly to total released mucus (26). These mucins together with proteins form the mucus layers that line the gastrointestinal tract. The layers exist as a firmly adhering gel layer that gives rise by enzymatic digestion to a superimposed loose layer that progressively dissociates into the lumen (39). The layers are thinnest in the small intestine, being only about $20 \%$ of the thickness of those in the stomach and colon $(\sim 100 \mu \mathrm{m})(40)$.

\section{Figure 9}

Perfusion system. Each end of a segment of intestine was ligated to a fire-polished glass capillary and suspended vertically inside a perfusion chamber made from a 10-cc plastic syringe. The perfusion chamber was sealed coaxially with rubber gaskets at each end to form a water jacket made from a 60-cc plastic syringe. The segment was perfused at constant flow from bottom to top, and samples were collected from the end of a silastic tube whose exit was held at a level at the top of the intestine to maintain a slightly positive pressure inside the segment to ensure luminal patency. Bathing solutions and gas were introduced through ports in the base of the bathing chamber as shown.

Mucus and fluid secretion. In addition to $\mathrm{HCO}_{3}{ }^{-}$, fluid secretion appears to be crucial for mucus transport. Mucus secreted from crypts and possibly from the base of villi presumably must be transported by secreted fluid to the lumen. Assuming that mucus from the crypts would be more dependent on fluid secretion than mucin from exposed villar tips, the fact that inhibiting fluid secretion with NKCC inhibitor bumetanide diminished mucus release by about $30 \%-50 \%$ (Figure 4 ) suggests that at least a portion of the released mucins must be from these structures. This finding raised the possibility that increased mucus release may be due simply to a $\mathrm{HCO}_{3}{ }^{-}$-dependent fluid lavage effect. However, the fact that neither the absence of $\mathrm{HCO}_{3}{ }^{-}$nor inhibition of $\mathrm{HCO}_{3}{ }^{-}$secretion with DIDS decreased fluid secretion argues strongly that the $\mathrm{HCO}_{3}{ }^{-}-$ dependent mucus release was not due to $\mathrm{HCO}_{3}{ }^{-}$-dependent fluid secretion (Figure 5). Thus, it seems unlikely that the $\mathrm{HCO}_{3}{ }^{-}$-dependent increase in stimulated mucus release is simply due to $\mathrm{HCO}_{3}{ }^{-}$dependent fluid secretion.

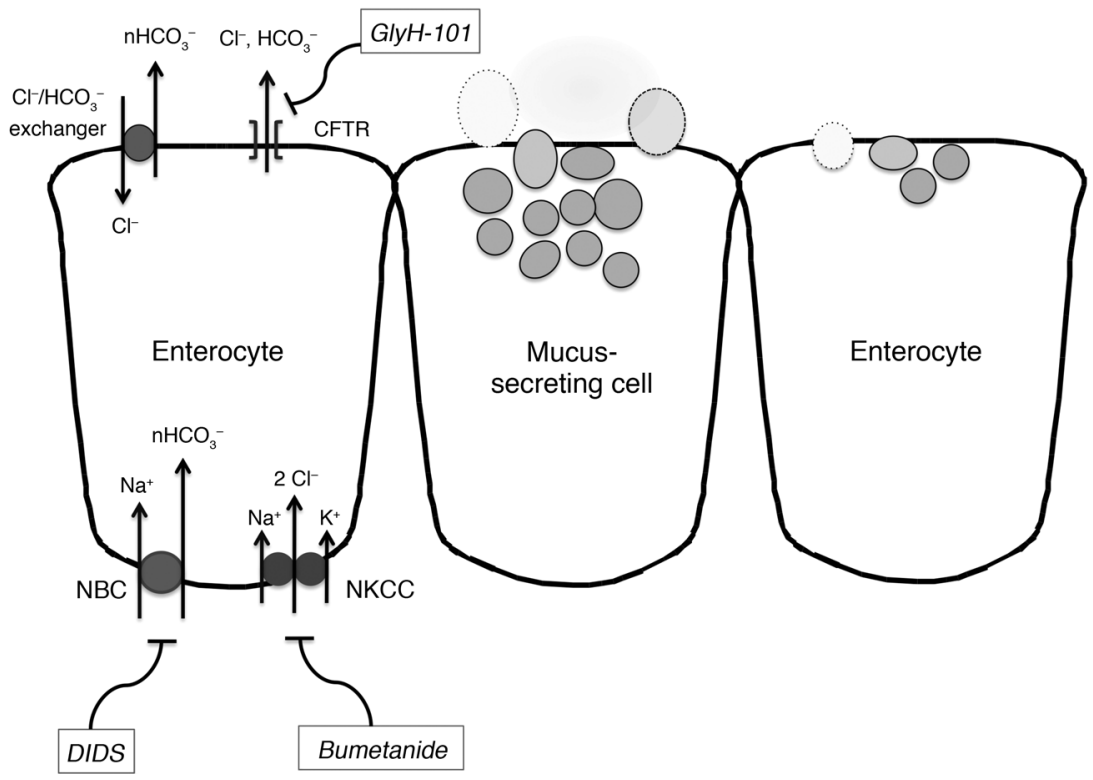

Figure 10

Conceptual arrangement of mucus cells and enterocytes with components of $\mathrm{Cl}^{-}$and $\mathrm{HCO}_{3}{ }^{-}$secretion and corresponding inhibitors. In general, $\mathrm{HCO}_{3}{ }^{-}$is thought to be taken up across the basolateral membrane mainly via NBC, which is inhibited by DIDS. $\mathrm{HCO}_{3}{ }^{-}$exits the cell across the apical membrane, possibly via a CFTR-dependent $\mathrm{Cl}-/ \mathrm{HCO}_{3}{ }^{-}$exchanger (also DIDS sensitive) or directly through the CFTR anion conductive channel that is inhibited by GlyH-101. Fluid secretion is dependent upon the uptake of $\mathrm{Cl}^{-}$via the NKCC in the basolateral membrane, which is inhibited by bumetanide and on CFTR (or other $\mathrm{Cl}^{-}$channels not shown) in the apical membrane. Thus, DIDS should block $\mathrm{HCO}_{3}{ }^{-}$secretion, and bumetanide should block fluid secretion. $\mathrm{GlyH}-101$ is expected to inhibit both $\mathrm{CFTR}$-dependent fluid and $\mathrm{HCO}_{3}{ }^{-}$secretion either directly by blocking CFTR conductance or indirectly by inhibiting a CFTR-dependent $\mathrm{Cl}^{-} / \mathrm{HCO}_{3}{ }^{-}$exchanger (65). The diagram intentionally suggests close proximity of $\mathrm{HCO}_{3}{ }^{-}$-secreting enterocytes, with mucus-secreting goblet cells and possibly enterocytes as a means of maintaining ample $\mathrm{HCO}_{3}{ }^{-}$in the immediate environment of secreted mucin granules. In CF, defunct CFTR would starve the environment of $\mathrm{HCO}_{3}^{-}$. 


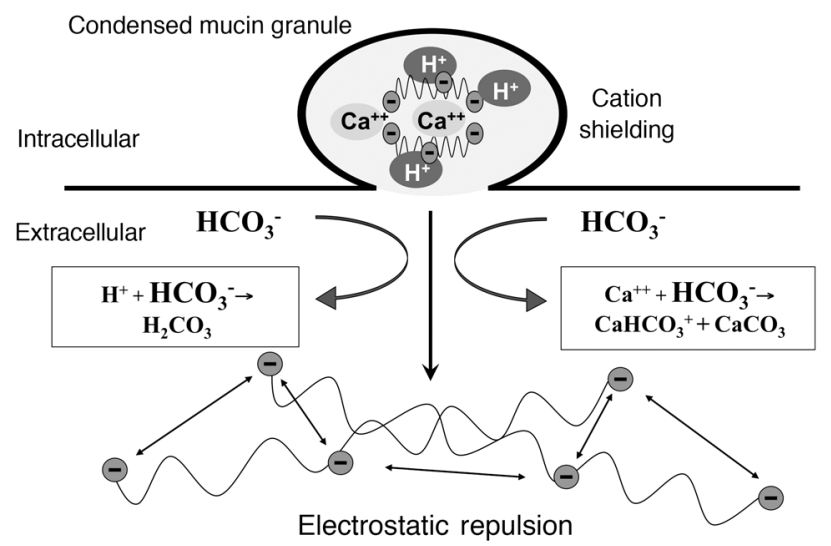

Figure 11

Possible mechanism for $\mathrm{HCO}_{3}{ }^{-}$-dependent expansion and solubilization of granules of condensed mucins. Intracellularly, mucins are condensed in granules by high concentrations of $\mathrm{Ca}^{2+}$ and $\mathrm{H}^{+}$, which shield the repulsive forces of the high density of negative charges on the anionic sites of mucin glycoproteins. As granules are secreted, released mucin must be accompanied by rapid dissociation of $\mathrm{Ca}^{2+}$ and $\mathrm{H}^{+}$from the mucin to unshield the fixed negative sites. The repulsive intramolecular electrostatic forces from exposed anionic sites then expand the mucin molecule extensively. Rapid expansion of the mucin molecule may be important to forming the network of macromolecules that become "normal mucus." Beyond this simplistic effect at the "moment of birth," however, $\mathrm{HCO}_{3}{ }^{-}$may be critically involved in other, more complicated processes for disaggregation and unraveling of mucin polypeptide domains and/or further interactions with proteins and other moieties. Thus, the presence of a competing anion such as $\mathrm{HCO}_{3}-$ in the extracellular media that efficiently sequesters these mucin-bound cations may optimize mucin expansion and intermolecular disaggregation, while its absence may bear heavily on the abnormal forms of aggregated mucus found in CF.

Mucus and $\mathrm{HCO}_{3}{ }^{-}$secretion. At least 2 observations seem to link $\mathrm{HCO}_{3}{ }^{-}$inexorably to mucus formation. First, $\mathrm{HCO}_{3}{ }^{-}$secretion and mucus properties are pervasively abnormal in CF $(22,41)$. Second, $\mathrm{HCO}_{3}{ }^{-}$secretion seems to accompany mucus secretion in most, if not all, normal conditions when mucus is secreted (20,42-44). The findings here that (a) removing $\mathrm{HCO}_{3}{ }^{-}$only from the serosal medium, (b) inhibiting basolateral $\mathrm{Na}^{+}-\mathrm{HCO}_{3}{ }^{-}$cotransport with DIDS, (c) inhibiting CFTR with GlyH-101, and (d) the loss of function with the $\Delta$ F508 mutation that results in faulty insertion of CFTR in the epithelial apical membrane all significantly blunted stimulated mucus release provide strong evidence that $\mathrm{HCO}_{3}{ }^{-}$is crucial for normal mucus formation.

However, when $\mathrm{HCO}_{3}{ }^{-}$was present only in the luminal perfusate, it was without detectable effect on stimulated mucus release (Figure 8). Given the complicated topography of the intestinal wall, it seems likely that perfused luminal $\mathrm{HCO}_{3}{ }^{-}$did not effectively reach the immediate sites of all mucus secretion in the lumens of the crypts and possibly in intervillar spaces in the wall of the intestine during perfusion. Indeed, $\mathrm{HCO}_{3}{ }^{-}$-free fluid secreted from the crypts would likely prevent $\mathrm{HCO}_{3}{ }^{-}$-containing luminal perfusate from entering these structures during stimulation. We do not know the source of secreted $\mathrm{HCO}_{3}{ }^{-}$, but it seems likely that it originates from either the base of the villi and/or the crypts (45), possibly via independent mechanisms $(36,38)$. Although there are reports that CFTR expression is present in intestinal goblet cells $(46,47)$, we would not expect these cells to be the main source of secreted $\mathrm{HCO}_{3}^{-}$, since they do not exhibit hallmark features of electrolyte-transporting cells. In any case, we suspect that $\mathrm{HCO}_{3}{ }^{-}$is secreted in close proximity to cells secreting mucins, as illustrated in Figure 10.

These combined results indicate that optimal mucin release into the intestinal lumen depends on both fluid and $\mathrm{HCO}_{3}{ }^{-}$secretion. They also seem consistent with results for tracheal submucosal glands $(48,49)$, in which inhibition of $\mathrm{HCO}_{3}{ }^{-}$transport appeared to thicken released mucus, although in those studies, the effects of decreased $\mathrm{HCO}_{3}{ }^{-}$were not separated from decreased fluid secretion.

It seems intuitive that fluid secretion is needed to carry mucins out of the lumens of the crypts and from between the villi, but how does $\mathrm{HCO}_{3}{ }^{-}$enhance the process of mucus release?

\section{Possible mechanisms for effect of $\mathrm{HCO}_{3}{ }^{-}$on mucus release}

The conditions for intracellular mucin packaging and mucus formation suggest a role for $\mathrm{HCO}_{3}{ }^{-}$in postexocytotic mucin release. Intracellularly, mucins must exist in a highly condensed form inside mucin granules or droplets that occupy as little as $1 / 1000$ of their extracellular gel volume after secretion (13). Extracellularly, physiological mucus is a tangled network of extremely long glycoproteins and proteins. Upon exocytosis, mucins are extended by strong repulsive electrostatic forces between a high density of negative charges fixed on the multitudinous oligosaccharide side chains of the mucin peptide backbone. The unpackaging and expansion of mucins from condensed granules to the final mucus layer is not well understood but likely to be complex. That is, enzymatic cleavage of peptide bonds between "packed" mucin polymers may be primary in mucin unraveling, and a proteolytic activity with an alkaline $\mathrm{pH}$ optimum firmly associated with mucus has been identified (I. Carlstedt, unpublished observations). Moreover, disassociation of the protein-protein domains of mucin oligomers may depend critically upon $\mathrm{Ca}^{2+}$ removal possibly via sequestering with $\mathrm{HCO}_{3}{ }^{-}$and $\mathrm{CO}_{3}{ }^{2-}$ (J. Sheehan, unpublished observations). Even beyond the process of expansion, since mucins are highly reactive substances, interactions with other moieties that participate in forming mucus may involve $\mathrm{HCO}_{3}{ }^{-}$as well, not to neglect the digestion and degradation that, as noted above, transform firm to loose and soluble mucus products (39).

While $\mathrm{HCO}_{3}{ }^{-}$might play a crucial role at any of these levels, we know that $\mathrm{pH}$ and $\mathrm{Ca}^{2+}$ levels appear to have profound effects on mucin expansion $(50,51)$, so that at this point, we propose the perhaps overly simplistic notion that the potential impact of $\mathrm{HCO}_{3}{ }^{-}$is on the mucin electrostatic interactions with $\mathrm{H}^{+}$and $\mathrm{Ca}^{2+}$. Verdugo introduced the idea that the repulsive forces of the fixed polyanionic charges of the oligosaccharide side chains that characterize all mucins are neutralized and shielded by high $\left[\mathrm{H}^{+}\right]$and $\left[\mathrm{Ca}^{2+}\right]$ within the granules $(50,52,53)$, and that as mucins are discharged from the granules, $\mathrm{Ca}^{2+}$ and $\mathrm{H}^{+}$must be removed from the negative sites to allow the repulsive electrostatic forces to extend and unravel the large, condensed mucin molecules. The rapid unshielding of fixed negative sites results in a virtual "explosion" of the glycoproteins into a continuous network of expanded "tangled strings" of macromolecules that largely determine the final properties of mucus $(13,52)$.

$\mathrm{HCO}_{3}{ }^{-}$is not only the most important extracellular buffer, but it is also well-suited to unshielding mucin anionic sites because it readily neutralizes $\mathrm{H}^{+}\left(\mathrm{H}_{2} \mathrm{CO}_{3}\right)$ and readily complexes with $\mathrm{Ca}^{2+}$ $\left(\mathrm{CaHCO}_{3}{ }^{+}\right.$and $\left.\mathrm{CaCO}_{3}\right)$ (54). Its presence thereby favors $\mathrm{H}^{+}$and $\mathrm{Ca}^{2+}$ disassociation from mucins by maintaining a low concentration of these free cations in solution. Thus, since $\mathrm{Cl}^{-}$, the other 

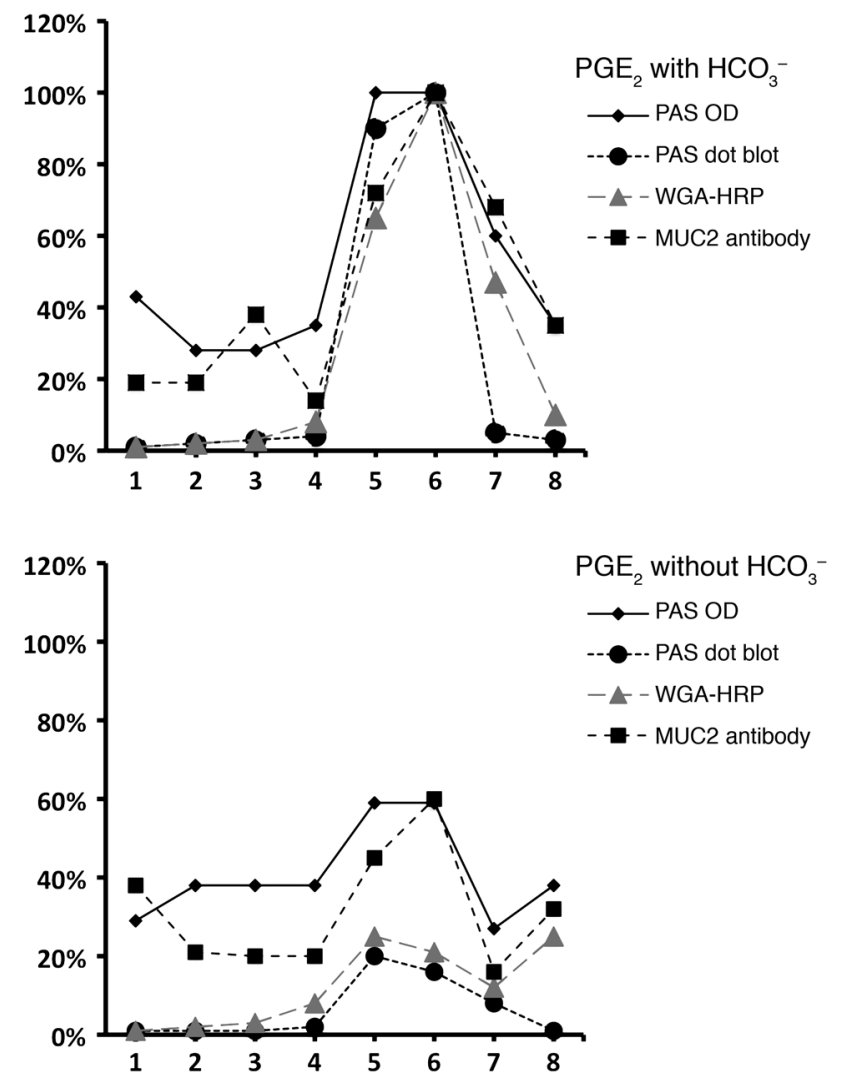

Figure 12

Assay validation for mucus content. A set of 8 sequential perfusates from each of a pair of intestinal segments was collected and assayed by 4 different methods for mucins. One segment was bathed in $\mathrm{HCO}_{3}{ }^{-}-$ containing $\left(2.5 \times 10^{-2} \mathrm{M}\right)$ and the other in $\mathrm{HCO}_{3}^{-}$-free Ringer. Upper panel: results of assays on perfusate samples from the intestinal segment bathed in $\mathrm{HCO}_{3}{ }^{-}$-buffered Ringer and stimulated with $\mathrm{PGE}_{2}$ after collecting perfusate sample no. 4. Lower panel: same as upper panel except the segment was incubated in the absence of $\mathrm{HCO}_{3}{ }^{-}$. Assays: PAS OD (diamonds): soluble PAS-positive material in liquid samples; PAS dot blot (circles): filtrands assayed for PAS-positive material retained on the Immobilon membrane; WGA-HRP (triangles): filtrands assayed for lectin-binding carbohydrates with HRP-tagged WGA lectin; Muc2 antibody (squares): filtrands assayed for Muc2 mucin with Muc2specific antibody labeled with HRP-tagged goat anti-rabbit second antibody. Since no assay gave the same quantitative amount of substance present as any other assay, results were normalized as a percentage of the maximal concentration for that assay, which consistently appeared shortly after addition of $\mathrm{PGE}_{2}$ in sample no. 6 in all assays and all experiments. In the lower panel, without $\mathrm{HCO}_{3}{ }^{-}$, all maximum values were less than $60 \%$ of the maximum values in the upper panel with $\mathrm{HCO}_{3}{ }^{-}$for each type of assay. Thus, independent of the type of assay, the relative amounts of products were similar for all assays. All showed that released product was maximal after $\mathrm{PGE}_{2}$ stimulation.

principal extracellular anion, has no affinity for $\mathrm{Ca}^{2+}, \mathrm{HCO}_{3}{ }^{-}$and $\mathrm{CO}_{3}{ }^{2-}$ are the significant anions available to sequester $\mathrm{Ca}^{2+}$ and $\mathrm{H}^{+}$ as mucins are released (Figure 11). In CF, the defect in transport should limit $\mathrm{HCO}_{3}{ }^{-}$availability to perform this role, which would limit mucin expansion and impede its disaggregation, transportability, and release into the lumen.

It seems noteworthy that the swelling rates (diffusivity) for mucus granules released from respiratory goblet cells (52) and from cul- tured cervical secretory cells increased significantly as the solution $\left[\mathrm{Ca}^{2+}\right]\left(1\right.$ to $\left.4 \times 10^{-3} \mathrm{M}\right)$ and $\left[\mathrm{H}^{+}\right](\mathrm{pH} 6.5-7.4)$ decreased (51). Just as pertinent, the swelling of mucus granules released from $\mathrm{CFTR}^{-/-}$ mouse gallbladder cells was substantially slower and their calcium content appreciably higher as compared with WT cells (55). Moreover, it has been recognized, but unexplained, for decades that relatively pure samples of several mucus-containing CF secretions harbor elevated calcium concentrations (55-58). Interestingly, intestinal crypt mucus and Paneth cell granules (which were found to accumulate in intestinal crypts in CF as does mucus) showed increased clearance and dissolution when CF mice were fed on a diet with $\mathrm{HCO}_{3}{ }^{-}$-rich polyethylene glycol laxative $(59,60)$.

\section{Conclusion}

With an ex vivo method, we have shown that dynamic mucin release can be monitored in segments of perfused native, intact murine small intestine and that $\mathrm{PGE}_{2}$ and $5-\mathrm{HT}$ are potent agonists for intestinal mucus release. We found that the absence of $\mathrm{HCO}_{3}{ }^{-}$or the inhibition of $\mathrm{HCO}_{3}{ }^{-}$transport decreases the amount and rate of stimulated mucus released and that inhibition of CFTR activity, either endogenously in transgenic mice or exogenously with inhibitors, also impedes mucus release. We suggest that $\mathrm{HCO}_{3}{ }^{-}$is essential for optimal extracellular mucin expansion and solubilization by virtue of its ability to sequester $\mathrm{Ca}^{2+}$ and $\mathrm{H}^{+}$, which exposes the repulsive electrostatic forces of polyanionic mucins and/or disaggregates other mucin interactions. Thus, $\mathrm{HCO}_{3}{ }^{-}$may serve to prevent the formation of aggregated mucus that is slow to release from the surfaces of the intestines and lumens of other hollow organs and causes mucus plugs characteristically seen in CF.

\section{Methods}

Animals. WT adult C57BL/6 mice (20-26 g) were either purchased from Harlan Sprague-Dawley Laboratory or taken from our own breeding colony and were maintained on standard laboratory chow and allowed free access to food and water. CFTR ${ }^{\text {tm } 1 \text { Kth }}$ mice (CF mice) carrying the most common human CFTR mutation, $\triangle \mathrm{F} 508$, on a CL57BL/6 background were received as a gift from Mitchell Drumm (Case Western Reserve University, Cleveland, Ohio, USA) and were bred and raised in our vivarium. Mice were maintained on Peptamen Junior (Nestle Nutrition) ad libitum with access to GoLYTELY (Braintree Laboratories) and pellets. Mice were anesthetized with ketamine $(100 \mathrm{mg} / \mathrm{kg})$ and xylazine $(10 \mathrm{mg} / \mathrm{kg})$ by subcutaneous injection for deep surgical anesthesia. When the hind limb flexor withdrawal reflex ceased, $12 \mathrm{~cm}$ of bowel proximal to the cecum was quickly excised and the animal was immediately sacrificed. UCSD's Institutional Animal Care and Use Committee approved all procedures used in this study.

Tissue preparation. Immediately after excision, the intestinal segments were placed in PBS-Ringer solution at room temperature, divided into proximal and distal halves (ca. $6 \mathrm{~cm}$ each), and assigned alternately as control and experimental segments, that is, half of the time the proximal segment was used a control and half of the time as experimental. Nifedipine $\left(10^{-6} \mathrm{M}\right)$ and indomethacin $\left(10^{-5} \mathrm{M}\right)$ were included in all solutions to prevent peristalsis and reduce endogenous PG release during tissue handling. Each segment of the intestine was carefully flushed with glucose-free PBSRinger solution to remove residual luminal contents. The segments were mounted and perfused vertically in a custom-designed perfusion chamber at $36 \pm 1^{\circ} \mathrm{C}$. Each end of a segment was ligated to the fire-polished end of a $2-\mathrm{cm}$ glass capillary, $1.2 \mathrm{~mm}$ in diameter. The capillaries with intestine attached were then supported from each end in a plastic chamber $(6 \mathrm{~cm}$ long and $16 \mathrm{~mm}$ in diameter) so that the segment was also held without stretching or bending. The lower glass capillary was connected by silastic 
tubing to a variable speed fluid pump adjusted to deliver the perfusate at 1 to $2 \mathrm{ml} / \mathrm{min}$. The upper capillary was also connected to a short piece of silastic tubing directed into an adjacent perfusate-collecting tube so that a small hydrostatic pressure (ca. $\sim 1 \mathrm{~cm} \mathrm{H}_{2} \mathrm{O}$ ) was constantly present in the lumen of the intestine (Figure 9).

Solution composition. The luminal perfusion Ringer solution always contained $150 \mathrm{mM} \mathrm{Na}^{+}, 2.5 \mathrm{mM} \mathrm{K}^{+}, 1 \mathrm{mM} \mathrm{Ca}^{2+}, 1 \mathrm{mM} \mathrm{Mg}^{2+}, 150 \mathrm{mM} \mathrm{Cl}^{-}$, and $2.5 \mathrm{mM} \mathrm{PO}_{4}{ }^{\mathrm{x}}$. The basolateral bathing solutions were the same, except that $10 \mathrm{mM}$ glucose was always present and $25 \mathrm{mM} \mathrm{HCO}_{3}^{-}$(substituted for equimolar $\mathrm{Cl}^{-}$) was included as indicated. Equimolar NMDG and gluconate were used to replace $\mathrm{Na}^{+}$and $\mathrm{Cl}^{-}$, respectively, as indicated. All solutions were adjusted to and maintained at $\mathrm{pH} 7.4$ by gassing to equilibrium with either $100 \% \mathrm{O}_{2}$ or $95 \% \mathrm{O}_{2}$ plus $5 \% \mathrm{CO}_{2}$ gas as appropriate during all protocols.

Other chemicals. Nifedipine, forskolin, and isobutylmethylxanthine (IBMX) were dissolved in DMSO, while indomethacin and $\mathrm{PGE}_{2}$ were dissolved in ethyl alcohol and added to serosal solutions as needed. All other agents were dissolved in Ringer solution directly. GlyH-101 was a gift from N. Sonowane and A. Verkman (UCSF). Lectin wheat germ agglutinin from Triticum vulgaris covalently linked to HRP (WGA-HRP) was obtained from Sigma-Aldrich. Primary rabbit polyclonal antibody (61) against synthetic MUC2 consensus tandem repeat sequences of MUC2 and second HRPtagged goat IgG anti-rabbit antibody were obtained from BioMeda.

Peristalsis inhibition. Antiperistaltic effects of different agents were evaluated by incubating intestinal segments in PBS-Ringer solution plus test drugs. Gross motor contractions of the intestinal segments were directly observed for at least 60 minutes, and the time required for contractions to cease was recorded. Assays were performed in triplicate.

Mucin collection. The lumens of all segments were perfused with glucosefree, $\mathrm{HCO}_{3}{ }^{-}$-free PBS-Ringer at a rate of approximately $0.5 \mathrm{ml} / \mathrm{min}$. The perfusates were collected at 5-minute intervals for basal measurements in $\mathrm{HCO}_{3}{ }^{-}$-free solutions during the initial 20 minutes of perfusion and then at approximately 3 -minute intervals after beginning the experimental protocols for an additional 20-30 minutes.

Mucin assays. We analyzed the mucin content of the luminal perfusates using PAS and lectin-binding assays. The PAS assay provides a simple, direct assay in solutions and tissues (62), which seemed well suited for measuring released mucus in this study, since it reacts with vicinal hydroxyl groups on carbohydrates regardless of mucin type. Glycogen could be a confounding PAS-positive substance, but the amount in intestinal cells should be inconsequential (63).

Assays: liquid aliquots. In brief, $0.2 \mathrm{ml}$ of periodic acid $0.1 \%$ was pipetted into each sample and incubated for 2 hours at $37^{\circ} \mathrm{C}$, after which $0.2 \mathrm{ml}$ of Schiff reagent (Sigma-Aldrich) was added and incubated for 30 minutes at room temperature. The OD of the resulting solution at 555 -nm wavelength was taken as a measure of the amount of PAS-positive product present (62) and assumed to be predominantly mucus. The concentrations of mucus in samples were assigned by interpolation of each sample OD from a plot of OD versus known concentrations of pig gastric mucin (Sigma-Aldrich).

Assays: filtrands. We applied the PAS assay to filtrands collected on methanol-activated Immobilon-P film (Millipore) from perfusate samples. An $80 \mu \mathrm{l}$ aliquot of sample or standard was pipetted into each well of a 96-well vacuum filter apparatus and aspirated through the filter film. The film was then immersed in periodic acid $0.5 \%$ for 15 minutes, rinsed thoroughly with deionized water, immersed in Schiff reagent for 30-60 minutes, and fixed with $3 \times$ rinses of sodium bisulfite $0.6 \%$. After rinsing in deionized $\mathrm{H}_{2} \mathrm{O}$ and drying, the film was digitally scanned and the color density of each dot was determined using Adobe Photoshop. The concentration of mucus in samples was assigned as above by interpolation of the density of each sample dot from a plot of dot density versus prepared concentrations of pig gastric mucin in samples handled identically.
For assurance that the PAS assays primarily reflected mucus (carbohydrate) content, we also applied a WGA-HRP-binding assay of filtrands of the same samples used for PAS assays prepared on films as described above. In this case, after aspirating the filtrate, the filtrands on the films were blocked with $3 \%$ BSA in TBS containing Triton X-100 for 2 hours and rinsed thoroughly in TBS. A DAB developer kit (Molecular Probes) was used according to the supplier's instructions to stain the filtrand dots. As above, the film was rinsed in deionized water, dried, digitally scanned, and interpolated against a plot of standards on the each film to determine the mucus concentrations of samples.

We recognize that all of these assays pertain to carbohydrate per se and not specifically to mucins. To further validate the use of these assays for mucin content in this protocol, we compared the results of 4 different assays on the same samples from an experiment. Perfusate samples were assayed by measuring the OD of PAS-positive product in sample solutions prepared as above as well as by the following 3 assays of filtrands of samples on Immobilon-P films: (a) PAS (as above), (b) WGA-HRP lectin binding (as above), and (c) Muc2 antibody-binding labeled with HRP-tagged mouse anti-rabbit IgG. Muc2 is a major secreted mucin in mouse small intestine (64). Although the 4 different assays did not yield absolute concentrations that were the same for each sample, the relative concentrations of assay products among all samples were the same for each assay (Figure 12). We took the presence of carbohydrates in the luminal perfusate to be proportional to mucus released into the lumen, since these assays agreed qualitatively with the mucin-specific antibody assay.

Fluid secretion. Segments of terminal ileum were resected and prepared as described above. One end of each segment was closed with braided suture, and approximately $0.1 \mathrm{ml}$ of either PBS-Ringer solution or NMDG-gluconate Ringer was instilled in each segment. Care was taken not to distend the lumen. The other end was then closed with a suture to create an intestinal sac. Each sac was gently blotted, weighed, placed in defined incubation media that was gassed with either $95 \% \mathrm{O}_{2}$ plus $5 \% \mathrm{CO}_{2}$ or $100 \% \mathrm{O}_{2}$, and warmed to $37^{\circ} \mathrm{C}$. After 30 minutes, the sacs were gently removed, delicately blotted, and reweighed. Increases and decreases in weight were interpreted as fluid secretion and as fluid absorption, respectively. Empty sacs were weighed before and after each protocol to assess tissue swelling, which appeared to be negligible. Weights were converted to volumes assuming specific density of $1.0 \mathrm{~g} / \mathrm{ml}$ for fluids.

Statistics. Values are expressed as mean \pm SEM. Statistical comparisons were made using a 2-tailed Student's $t$ test for single-value comparisons, 2-tailed ANOVA with the Scheffe's test to adjust for multiple comparisons (i.e., fluid secretion analysis), and 2-way repeated-measures ANOVA for sequential, timed data analysis. $P<0.05$ was considered significant.

\section{Acknowledgments}

This work was supported by the Nancy Olmsted Trust (NIHNHLB RO1-HL084042) and the Cystic Fibrosis Foundation. The authors thank Guillermo Flores-Delgado for his assistance with assays and with mutant mice genotyping, and Kirk Taylor for technical assistance. Statistical assistance was provided in part by NIH grant MO1 RR-00827 for the UCSD General Clinical Research Center.

Received for publication January 21, 2009, and accepted in revised form July 1, 2009.

Address correspondence to: Paul M. Quinton, UCSD School of Medicine, Department of Pediatrics, 9500 Gilman Drive, La Jolla, California 92093-0831, USA. Phone: (619) 543-9635; Fax: (619) 543-5642; E-mail: pquinton@ucsd.edu. 
1. Thomsson, K.A., et al. 2002. Intestinal mucins from cystic fibrosis mice show increased fucosylation due to an induced Fucalpha1-2 glycosyltransferase. Biochem. J. 367:609-616.

2. Zhang, Y., Doranz, B., Yankaskas, J.R., and Engelhardt, J.F. 1995. Genotypic analysis of respiratory mucous sulfation defects in cystic fibrosis. J. Clin. Invest. 96:2997-3004.

3. Davril, M., et al. 1999. The sialylation of bronchial mucins secreted by patients suffering from cystic fibrosis or from chronic bronchitis is related to the severity of airway infection. Glycobiology. 9:311-321.

4. Finkbeiner, W.E. 1999. Physiology and pathology of tracheobronchial glands. Respir. Physiol. 118:77-83.

5. Mantle, M., Stewart, G., Zayas, G., and King, M. 1990 The disulphide-bond content and rheological properties of intestinal mucins from normal subjects and patients with cystic fibrosis. Biochem. J. 266:597-604.

6. Parmley, R.R., and Gendler, S.J. 1998. Cystic fibrosis mice lacking Muc1 have reduced amounts of intestinal mucus. J. Clin. Invest. 102:1798-1806.

7. Henke, M.O., Renner, A., Huber, R.M., Seeds, M.C., and Rubin, B.K. 2004. MUC5AC and MUC5B mucins are decreased in cystic fibrosis airway secretions. Am. J. Respir. Cell Mol. Biol. 31:86-91.

8. Van Klinken, B.J., Dekker, J., Buller, H.A., and Einerhand, A.W. 1995. Mucin gene structure and expression: protection vs. adhesion. Am. J. Physiol. 269:G613-G627.

9. Oppenheimer, E.H., and Esterly, J.R. 1975. Pathology of cystic fibrosis review of the literature and comparison with 146 autopsied cases. Perspect. Pediatr. Pathol. 2:241-278.

10. Matsui, H., et al. 1998. Evidence for periciliary liquid layer depletion, not abnormal ion composition, in the pathogenesis of cystic fibrosis airways disease. Cell. 95:1005-1015.

11. Ma, T., and Verkman, A.S. 1999. Aquaporin water channels in gastrointestinal physiology. J. Physiol. 517:317-326

12. Tam, P.Y., and Verdugo, P. 1981. Control of mucus hydration as a Donnan equilibrium process. Nature. 292:340-342

13. Verdugo, P. 1990. Goblet cells secretion and mucogenesis. Annu. Rev. Physiol. 52:157-176.

14. Poulsen, J.H., Fischer, H., Illek, B., and Machen, T.E. 1994. Bicarbonate conductance and $\mathrm{pH}$ regulatory capability of cystic fibrosis transmembrane conductance regulator. Proc. Natl. Acad. Sci. U. S. A. 91:5340-5344.

15. Reddy, M.M., and Quinton, P.M. 2003. Control of dynamic CFTR selectivity by glutamate and ATP in epithelial cells. Nature. 423:756-760.

16. Clarke, L.L., Stien, X., and Walker, N.M. 2001. Intestinal bicarbonate secretion in cystic fibrosis mice. JOP. 2:263-267.

17. Choi, J.Y., et al. 2001. Aberrant CFTR-dependent HCO3- transport in mutations associated with cystic fibrosis. Nature. 410:94-97.

18. Hogan, D.L., et al. 1997. Acid-stimulated duodenal bicarbonate secretion involves a CFTR-mediated transport pathway in mice. Gastroenterology. 113:533-541

19. Pratha, V.S., et al. 2000. Identification of transport abnormalities in duodenal mucosa and duodenal enterocytes from patients with cystic fibrosis. Gastroenterology. 118:1051-1060.

20. Joo, N.S., et al. 2001. HCO3-transport in relation to mucus secretion from submucosal glands. JOP. 2:280-284

21. Scheele, G.A., Fukuoka, S.I., Kern, H.F., and Freedman, S.D. 1996. Pancreatic dysfunction in cystic fibrosis occurs as a result of impairments in luminal $\mathrm{pH}$, apical trafficking of zymogen granule membranes, and solubilization of secretory enzymes. Pancreas. 12:1-9.

22. Quinton, P.M. 2008. Cystic fibrosis: impaired bicarbonate secretion and mucoviscidosis. Lancet. 372:415-417.
23. Farber, S. 1945. Some organic digestive disturbances in early life. Journal of Michigan State Medical Society. 44:587-594.

24. Donnelly, G., et al. 2001. The myogenic component in distention-induced peristalsis in the guinea pig small intestine. Am. J. Physiol. Gastrointest. Liver Physiol. 280:G491-G500.

25. Praetorius, J., et al. 2001. Molecular and functional evidence for electrogenic and electroneutral $\mathrm{Na}(+)$ $\mathrm{HCO}(3)(-)$ cotransporters in murine duodenum. Am J. Physiol. Gastrointest. Liver Physiol. 280:G332-G343.

26. Halm, D.R., and Halm, S.T. 2000. Secretagogue response of goblet cells and columnar cells in human colonic crypts. Am. J. Physiol. Cell Physiol. 278:C212-C233.

27. Chambers, L.A., Rollins, B.M., and Tarran, R. 2007. Liquid movement across the surface epithelium of large airways. Respir. Physiol. Neurobiol. 159:256-270.

28. Haas, M., and McManus, T.J. 1983. Bumetanide inhibits $(\mathrm{Na}+\mathrm{K}+2 \mathrm{Cl})$ co-transport at a chloride site. Am. J. Physiol. 245:C235-C240.

29. Muanprasat, C., et al. 2004. Discovery of glycine hydrazide pore-occluding CFTR inhibitors: mechanism, structure-activity analysis, and in vivo efficacy. J. Gen. Physiol. 124:125-137.

30. Neutra, M.R., O'Malley, L.J., and Specian, R.D. 1982. Regulation of intestinal goblet cell secretion. II. A survey of potential secretagogues. Am. J. Physiol. 242:G380-G387.

31. Phillips, T.E., Phillips, T.H., and Neutra, M.R. 1984. Regulation of intestinal goblet cell secretion. III. Isolated intestinal epithelium. Am. J. Physiol. 247:G674-G681.

32. Malmberg, E.K., et al. 2006. Increased levels of mucins in the cystic fibrosis mouse small intestine, and modulator effects of the Muc1 mucin expression. Am. J. Physiol. Gastrointest. Liver Physiol. 291:G203-G210.

33. Peregrin, A.T., Ahlman, H., Jodal, M., and Lundgren, O. 1999. Involvement of serotonin and calcium channels in the intestinal fluid secretion evoked by bile salt and cholera toxin. Br. J. Pharmacol. 127:887-894.

34. Akiba, Y., et al. 2001. Sensory pathways and cyclooxygenase regulate mucus gel thickness in rat duodenum. Am. J. Physiol. Gastrointest. Liver Physiol. 280:G470-G474

35. Plaisancie, P., et al. 1998. Effects of neurotransmitters, gut hormones, and inflammatory mediators on mucus discharge in rat colon. Am. J. Physiol. 275:G1073-G1084.

36. Seidler, U., et al. 1997. A functional CFTR protein is required for mouse intestinal cAMP-, cGMPand $\mathrm{Ca}(2+)$-dependent $\mathrm{HCO} 3$ - secretion. J. Physiol. 505:411-423.

37. Berner Hansen, M., and Witte, A.B. 2008. The role of serotonin in intestinal luminal sensing and secretion. Acta Physiol. (Oxf.). 193:311-323.

38. Takeuchi, K., Aihara, E., Hayashi, M., and Sasaki, Y. 2005. Role of prostaglandin E receptor subtypes in gastroduodenal HCO3- secretion. Med. Chem. 1:395-403.

39. Johansson, M.E., et al. 2008. The inner of the two Muc2 mucin-dependent mucus layers in colon is devoid of bacteria. Proc. Natl. Acad. Sci. U. S. A. 105:15064-15069.

40. Atuma, C., Strugala, V., Allen, A., and Holm, L. 2001. The adherent gastrointestinal mucus gel layer: thickness and physical state in vivo. Am.J. Physiol. Gastrointest. Liver Physiol. 280:G922-G929.

41. Quinton, P.M. 2001. The neglected ion: HCO3. Nat. Med. 7:292-293.

42. Allen, A., Flemstrom, G., Garner, A., and Kivilaakso, E. 1993. Gastroduodenal mucosal protection. Physiol. Rev. 73:823-857.

43. Sababi, M., Nilsson, E., and Holm, L. 1995. Mucus and alkali secretion in the rat duodenum: effects of indomethacin, $\mathrm{N}$ omega-nitro-L-arginine, and luminal acid. Gastroenterology. 109:1526-1534.

44. Vishwakarma, P. 1962. The $\mathrm{pH}$ and bicarbonate- ion content of the oviduct and uterine fluids. Fertil. Steril. 13:481-485.

45. Simpson, J.E., Gawenis, L.R., Walker, N.M., Boyle, K.T., and Clarke, L.L. 2005. Chloride conductance of CFTR facilitates basal Cl-/HCO3- exchange in the villous epithelium of intact murine duodenum. Am.J. Physiol. Gastrointest. Liver Physiol. 288:G1241-G1251.

46. Hayden, U.L., and Carey, H.V. 1996. Cellular localization of cystic fibrosis transmembrane regulator protein in piglet and mouse intestine. Cell Tissue Res. 283:209-213.

47. Kalin, N., Claass, A., Sommer, M., Puchelle, E., and Tummler, B. 1999. DeltaF508 CFTR protein expression in tissues from patients with cystic fibrosis. J. Clin. Invest. 103:1379-1389.

48. Inglis, S.K., Corboz, M.R., and Ballard, S.T. 1998. Effect of anion secretion inhibitors on mucin content of airway submucosal gland ducts. Am. J. Physiol. 274:L762-L766.

49. Joo, N.S., Saenz, Y., Krouse, M.E., and Wine, J.J. 2002. Mucus secretion from single submucosal glands of pig. Stimulation by carbachol and vasoactive intestinal peptide. J. Biol. Chem. 277:28167-28175.

50. Verdugo, P. 1984. Hydration kinetics of exocytosed mucins in cultured secretory cells of the rabbit trachea: a new model. Ciba Found. Symp. 109:212-225.

51. Espinosa, M., Noe, G., Troncoso, C., Ho, S.B., and Villalon, M. 2002. Acidic $\mathrm{pH}$ and increasing $[\mathrm{Ca}(2+)]$ reduce the swelling of mucins in primary cultures of human cervical cells. Hum. Reprod. 17:1964-1972.

52. Verdugo, P., Deyrup-Olsen, I, Aitken, M., Villalon, M., and Johnson, D. 1987. Molecular mechanism of mucin secretion: I. The role of intragranular charge shielding. J. Dent. Res. 66:506-508.

53. Paz, H.B., et al. 2003. The role of calcium in mucin packaging within goblet cells. Exp. Eye Res. 77:69-75.

54. Hodge, H.C. 1955. Some achievements and problems in studying the solubility of the mineral of the hard tissues. Ann. N. Y. Acad. Sci. 60:661-669.

55. Kuver, R., Wong, T., Klinkspoor, J.H., and Lee, S.P. 2006. Absence of CFTR is associated with pleiotropic effects on mucins in mouse gallbladder epithelial cells. Am. J. Physiol. Gastrointest. Liver Physiol. 291:G1148-G1154.

56. Lorin, M.I., Gaerlan, P.F., Mandel, I.D., and Denning, C.R. 1976. Composition of nasal secretion in patients with cystic fibrosis. J. Lab. Clin. Med. 88:114-117.

57. Mandel, I.D., et al. 1969. Calcium and phosphorus levels in submaxillary saliva. Changes in cystic fibrosis and in asthma. Clin. Pediatr. (Phila.). 8:161-164.

58. Kopito, L.E., Kosasky, H.J., and Shwachman, H. 1973. Water and electrolytes in cervical mucus from patients with cystic fibrosis. Fertil. Steril. 24:512-516.

59. Clarke, L.L., et al. 2004. Abnormal Paneth cell granule dissolution and compromised resistance to bacterial colonization in the intestine of CF mice. Am.J. Physiol. Gastrointest. Liver Physiol. 286:G1050-G1058.

60. De Lisle, R.C., Roach, E., and Jansson, K. 2007. Effects of laxative and $\mathrm{N}$-acetylcysteine on mucus accumulation, bacterial load, transit, and inflammation in the cystic fibrosis mouse small intestine. Am. J. Physiol. Gastrointest. Liver Physiol. 293:G577-G584.

61. Stanley, C.M., and Phillips, T.E. 1999. Selective secretion and replenishment of discrete mucin glycoforms from intestinal goblet cells. Am. J. Physiol. 277:G191-G200.

62. Kirkeby, S., Moe, D., Bog-Hansen, T., Garbarsch, C., and Matthiessen, M.E. 1992. Quantitative PAS assay of some carbohydrate compounds and detergents. J. Biochem. Biophys. Methods. 24:225-238.

63. Thomopoulos, G.N., et al. 2001. Ultrastructural changes in exocrine tissues of a DeltaF-508 CFTR mouse model. Pflugers Arch. 443 (Suppl. 1):S28-S35.

64. van Klinken, B.J., et al. 1999. Gastrointestinal expression and partial cDNA cloning of murine Muc2. Am. J. Physiol. 276:G115-G124.

65. Wang, Y., et al. 2006. Slc26a6 regulates CFTR activity in vivo to determine pancreatic duct $\mathrm{HCO} 3$ - secretion: relevance to cystic fibrosis. $E M B O J$ J 25:5049-5057. 